\title{
Exploring the Principles and Laws of Financial Crisis: from the Subprime Mortgage Crisis to New Crown Epidemic
}

\author{
Wang Shuhao
}

\author{
University of Warwick, Coventry CV4 7AL, UK \\ Email: wangshuhao1997@126.com
}

\begin{abstract}
Financial crisis has stimulated debates among analysts as they strive to detect and reduce the impact of recession before it undermines the global economy's development. The challenges that the financial crisis imparts in nations are becoming intense due to globalization. Moreover, capital markets are evolving from domestic to national boundaries, consequently attracting fiscal challenges. This exposes the global economy to the subprime mortgage crisis. Contextually, the research topic focuses on exploring the principles and laws of financial turmoil that promote economic stability. Besides, it highlights crucial experiences that act as lessons. The research focuses on five types of financial crises which include, - banking crisis, currency crisis, public debt crisis, inflation crisis, and balance of payment crisis. Afterward, causes of financial instability and consequences act as tools that help assess laws and principles that guide global economic development. By analyzing secondary data from past financial reports, this paper displays that capital markets' amalgamation impacts the global economy whenever one nation encounters setbacks from poor monetary policies. Notably, speculators and pandemics impact on the subprime mortgage crisis. The prospective suggestions for follow-up research are placed in the conclusion.
\end{abstract}

Keywords: Financial market, global economy, financial crisis, subprime mortgage crisis

\section{INTRODUCTION}

The laws and principles of financial crisis entail regulations on insurance, derivative markets, and, banking sector. Additionally, these laws guide portfolio management and capital markets. Ideally, the financial crisis's principles and laws highlight market practices that promote liquidity in case of financial distress. Financial laws are essential in the global economy since they assist in forming legal policies that guide financial transactions. Private and public sectors ought to comprehend corporate laws due to their impact in financial markets. When a financial crisis is ignored, a country is exposed to a recession, just like the subprime mortgage crisis in the US that resulted in a devaluation of housing rates. In the contemporary business world, a financial crisis is inevitable and has evolved to be a new crown epidemic. The paper focuses on the financial crisis's principles and laws with the subprime mortgage crisis in the new crown epidemic.

\subsection{Background Information}

Financial crisis refers to a decline in the value of assets and securities, which results in losses in financial institutions. Financial law and principles guide insurance firms, banks, investment management, and capital markets. It provides a framework for smooth operations in the global economy. Ideally, the 20072009 global financial crisis inflicted damage to the public and private sectors, which provoked banks and governments to develop policies that could overcome economic distress [1]. Countries that emulate central bank policies like deposit protection measures manage to mitigate risks when a bubble bursts.

\subsection{Problem Statement}

Challenges that macro institutions are obliged to tackle during financial distress entails credit booms and bursts, which creates instability in the market. The impact of asset price and credit burst is costly since it enhances a recession. With financial panics, macro 
economies make abrupt decisions to liquidate their assets to meet lenders' terms and requirements. Notably, they avoid further losses since prices of commodities plummets.

\subsection{Research Tools}

In the 2007 financial crisis, housing prices in most countries increased. However, in the US, mortgage rates were low since the Federal Reserve stated that banks lent money to other institutions overnight. Therefore, in a financial crisis, subprime mortgages are easy to obtain. According to research, a financial crisis relates to an epidemic since they begin like an eruption and spread to other areas. Notably, an epidemic imparts negative consequences that result in economic disparity, especially in emerging markets.

\subsection{Significance}

The formulation of ecological approaches that would enhance future research on a financial crisis is essential. While evaluating the financial crisis categories, comprehending the devastating impacts like a decline in Gross Domestic Product (GDP) and hoarding behavior of brokers is essential. The disastrous effect of the great depression in 2008 displayed unfavorable banking practices and market participants' actions like subprime mortgage lenders, brokers, institutions, and regulatory firms, which is portrayed in the study. According to the paper, understanding the effects of the financial crisis helps analysts evaluate ethical considerations that stimulate economic growth. The study of principles and laws of a financial crisis is vital in determining inflated asset prices that boost bubble in bonds and real estate. It also provides details on how excessive borrowing, which enhances leverage in financial institutions, attracts uncertainties. The paper aims at arguing how principles and laws of financial crisis directly relate to subprime mortgages and pandemics.

\subsection{Types of Financial Crisis}

\subsubsection{Currency crisis}

Currency crisis emanates from speculative aspects of the value of a currency. This leads to a decrease in the value of a domestic currency since the government fails to implement financial laws and principles, consequently attracting poor financial conditions. As a result, a country strives to stabilize its value and avoid depreciation by increasing interest rates. More so, the central bank increases currency circulation through boosting expenditure in the international reserves [2]. This type of financial instability groups into currency crash where countries compare their annual depreciation with the US dollar. The first type of currency debasement focuses on decreasing metallic circulation that represents monetary value. The second category of currency debasement originates from the replacement of a depreciated currency that was in circulation.

\subsubsection{Banking crisis}

This type of crisis originates from fragile entities like the maturity period of loans and liquidity. Notably, during this period, banks continuously lose large amounts of capital from their reserves. Many institutions depend on leveraged balance sheets. This favors coordination where stakeholders can withdraw their capital reserves, consequently influencing other individuals to follow suit. This fear creates small shocks and eventually facilitates turmoil in the financial market. When the public struggles to attain a particular payment means, monetary loss and recession are inevitable. This can be avoided through intervention by a lender of last resort. During a bank crisis, two types of events occur. In the first process, a bank runs result in merger and closure. In the other event, whenever government regulations do not intervene in the banking crisis, other financial facilities are exposed to negative consequences.

\subsubsection{Public Debt crisis}

In a public debt crisis, a country fails to service its obligations that originate from foreign debts. More so, domestic liabilities intensify the public debt crisis. A country fails to adhere to the required date of principal and interest payment in a sovereign default. In pandemics, a nation can exhaust its contingency funds and opt for external borrowings with high-interest rates. In such a case, "the country is prone to repudiations," according to the International Monetary Fund (IMF). When external borrowings increase quickly within a short period, the government is exposed to indebtedness. This was evident in the first decade of the 21st century, where countries in the Eurozone and the US encountered large debts that exposed their uncredited worthy status. When a government decides to increase expenditure but fails to acknowledge suitable sources to service revenues, default on public debts is inevitable due to high-interest rates on the principal amount. Private and public sectors do not perform efficiently when a country has vast public debts due to a lack of funds in the economy.

\subsubsection{Inflation and Balance of Payment crisis}

When inflation increases, borrowers, including national governments, are obliged to pay higher loans than the initial borrowed value. Contextually, inflation causes the purchasing power to decrease compared to the initial period. In mortgages, property rates are valued at higher prices, consequently discouraging investors [3]. With a balance of payment crisis, a deficit 
occurs in the current and capital account hence exhausting the national reserve. In this crisis, a country fails to offset its external debts and cannot acquire essential imports. According to studies, before the balance of payment crisis occurs, there is an increase in capital inflows, which signals growth. However, the local economy depresses since a country spends many resources from the capital and current account strategically to increase funds flow. To amend this crisis, the government needs to balance internal prices while relating the demand for commodities to enhance productivity.

\subsection{Causes of a Financial Crisis}

\subsubsection{Asset price boom and bursts}

Bubble in assets occurs when prices increase sharply, which is often followed by a crash. In some cases, assets display unfavorable characteristics that undermine perfect structures in financial markets. According to financial analysts, a bubble entails an upward rise in asset prices caused by economic conditions. When a bubble crashes, financial distress is inevitable, just like the French Mississippi bubble in 1719-1720. Another bubble happened in the South Sea in the United Kingdom. Individual behavior influences the price of assets. Also, information asymmetry contributes to mispricing, where investors fail to incorporate market conditions on costs. Micro and macro elements contribute to a bubble. When an agency borrows loans like a mortgage for housing to invest and mitigate risks, they can default when future payments are high. Like fund managers who receive more rewards on the upside than on the downside, they expose their assets to uncertainties that foster a bubble.

\subsubsection{Credit boom and bursts}

Before a financial crisis, a rapid increase in credit is expected. Factors like leverage growth and credit expansion boost the rise in asset prices. According to studies, shocks and structural modifications in the market contribute to credit boom and bursts. Additionally, economic policies and capital flow influence the Gross Domestic Product (GDP), which increases the likelihood of a credit boom. Claessens \& Kose suggest that before a boom occurs, the GDP growth rate is perceived to be $5.1 \%$ in the preceding three year period. When a country engages in international trade, an increase in financial flows facilitates credit booms due to foreign borrowings' availability. Studies indicate that the credit boom attracts a crisis due to growth in borrowers and lenders' leverage. In such a scenario, the lending standards are deplorable and attract systematic uncertainties. Cyclical fluctuations in economic activities result in low interest rates and a decline in debt service, which helps undermine credit booms and bursts. Such conditions expose households to indebtedness due to a lack of suitable credit requirements.

\subsubsection{Governance}

For an efficient financial system, the interconnection between effective governance and citizens helps prevent a financial crisis that emanates from pandemics and poor economic policies. A democratically civil society focuses on economic development by developing suitable monetary policies like favorable stock exchange regulations. Ideally, employing contractionary and expansionary measures assists countries in avoiding financial distress. Stakeholders and regulators play a significant role in corporate governance, which influences the performance of companies. For efficient management of organizations, the board of directors considers risk management, performance appraisal, shareholder's wealth maximization, and payment of bonuses. These elements affect the inflow and outflow of capital in organizations, which is vital since it influences financial distress. With risk management, a company asses a viable technique that assists in mitigating uncertainties that exposes them to liquidity risks and insolvency. The payment structure is equally essential because employees receive short term investments, which boosts long-term growth. Performance appraisal incorporates financial analysis where deficits are known in advance and assist the management in attaining objectives. When a company fails to incorporate corporate management in administration, the financial crisis emanates from poor planning.

\subsection{Implications of a Financial Crisis}

A financial crisis triggers an economic recession due to growth in the cost of livings. Financial instability relates to decline in a variety of macroeconomic aggregates. With a recession, factors like consumption, investment, employment, and industrial production decreases [4]. Besides, when a country experiences financial disparity, exports and imports deteriorate since its monetary value decreases, hence not attracting foreign exchange. Recession negatively impacts the real economy, where banks lack credit facilities to support their operations. Financial institutions encounter a lack of growth with a bank crisis because they cannot expand their activities.

During a financial crisis, the global output decreases because of lower productivity. During WWII, the world encountered a recession since resources were destroyed, and violence had destabilized several markets. In 2009, the great depression resulted in a decline in the world's GDP by $2 \%$. In 1991, the global recession affected credit markets, thus reducing several nations [5]. 
According to reports, the per capita GDP decreased by $0.8 \%$ in 1982. In 1991, the global GDP declined by $0.2 \%$. Another implication of the financial crisis relies on bank structuring, where pay off on dividends and incentives to stakeholders should be adjusted to ensure the economy's optimal performance. Government plays a significant role in preventing debt distress among households according to research.

\section{CONCLUSION}

Lessons that are evident in this study highlight the importance of macroeconomic and monetary policies, which are essential in controlling the subprime mortgage crisis and pandemic factors that foster financial instability. Indeed, the government plays a significant role in curbing poor economic development. This research displays how economies ought to be careful when transitioning from an emerging economy to a liberal economy due to speculators' emergence that deteriorates market conditions. Furthermore, from the study, the principle and law of financial crisis indicate that the amalgamation of universal markets influences single markets' operations due to the chain effect that it upholds.

\subsection{Shortcomings}

This study's shortcomings focus on methodology where the readers fail to comprehend the implemented research design. In the information analyzed, it is not disclosed whether it was primary data or secondary data. Another limitation in the study entails the lack of a population sample that is being investigated. The task ought to describe the methodology design that was implemented, which was a retrospective study. Notably, it is a report that focuses on past phenomenon. The methodology section would have provided details on the secondary data collected due to the passive gathering of information. Identification of a sample population is essential because it assists learners in understanding the elements of the research.

\subsection{Future Research}

Future research ought to focus on short-term financial techniques that assist in reducing the impact of a recession. Previous studies have shown the importance of credit and risk management strategies that contribute to economic growth [6]. However, globalization has introduced new elements emanating from pandemic and subprime mortgages that require intensive measures. An international financial architecture that acknowledges developed and developing economies is vital for the future development of mitigation strategies [7]. Innovations on financial systems should consider developing nations before implementing procedures aiming to promote a suitable international monetary system [8].

\section{ACKNOWLEDGMENT}

I am grateful to my professor, who guided and supported me in finalizing the research. Additionally, my professor made this research enjoyable. I came to comprehend many new themes through this research, and I am thankful. For the successful completion of this research, I am entirely grateful to God. I am indebted to the University, especially the faculty of Business and Economics, to grant me the opportunity to pursue my undergraduate course and make this industrial research project a part of my program. I extend my gratitude to the school library, where I obtained vital information that contributed to this paper's conclusion.

\section{REFERENCES}

[1] S. Claessens, and M. M. A. Kose.Financial Crises Explanations, Types, and Implications, International Monetary Fund, 2013, pp: 13-28.

[2] E. Račickas and A. Vasiliauskaitè. Classification of Financial Crises Their Occurrence Frequency in Global Financial Markets. Socialiniai tyrimai, Vol. 4, pp: 32-44.

[3] S. Merovci, D. Konxheli, and M. A. Sahiti. Types of Financial Crisis. Asian Journal of Business and Management Sciences, 2011, Vol. 2, No. 12, pp: 31-39.

[4] W. J. McKibbin, and A. Stoeckel. The Global Financial Crisis: Causes and Consequences. Asian Economic Papers, 2010, Vol. 9, No. 1, pp: 54-86.

[5] R. Mohan. Global Financial Crisis: Causes, Impact, Policy Responses and Lessons, 2009.

[6] D. Singh, and J. R. LaBrosse. Developing a framework for effective financial crisis management. Financial Market Trends, 2011, Vol. 2.

[7] R. Peckham. Economies of Contagion: Financial Crisis and Pandemic. Economy and Society,2013, Vol. 42, No. 2, pp: 226-248.

[8] W.Naudé. The Financial Crisis of 2008 and the Developing Countries (No. 2009/01). WIDER Discussion Paper, 2009. 